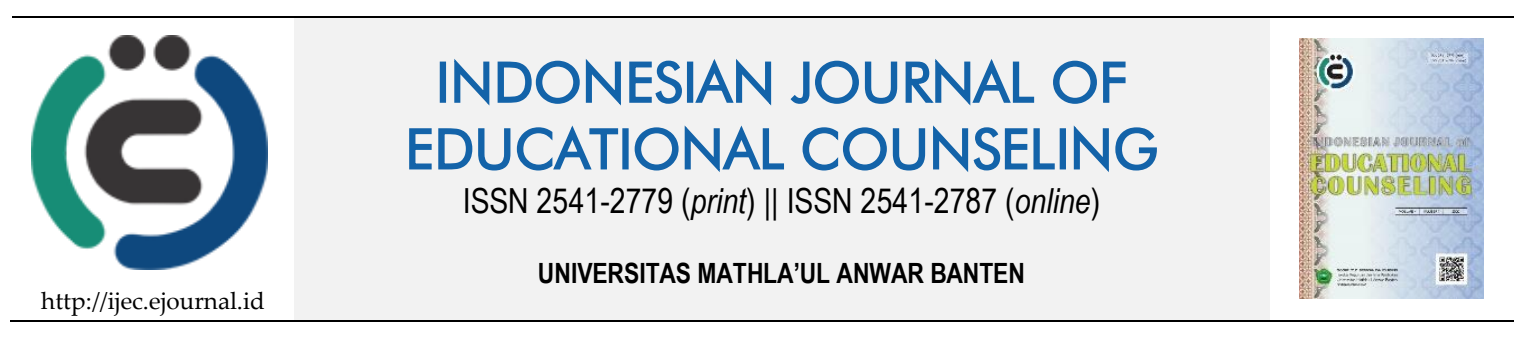

Research Based Article

\title{
Upaya Pengembangan Diri Siswa melalui Layanan Bimbingan dan Konseling Sekolah Menengah Atas di Provinsi Banten
}

\author{
Salman Tumanggor ${ }^{1}$
}

${ }^{1}$ Universitas Islam Negeri Syarif Hidayatullah Jakarta, Indonesia

\begin{tabular}{ll}
\hline Article History & ABSTRACT \\
\hline Received: 21.08.2019 & SELF-STUDENTS DEVELOPMENT BY GUIDANCE AND COUNCELING \\
Received in revised form: & SERVICE IN HIGH SCHOOL AT BANTEN PROVINCE. Guidance and \\
Accepted: 19.12 .2019 & counseling program organized to support the achievement of the educational \\
Available online: 30.01 .2020 & objectives of the school as a whole. The based goal is essentially to prepare \\
& students through guidance, teaching, and training for their roles in the future. \\
& The efforts of self-development especially the high school student are the \\
& principal leadership approach to motivated the resources in school the are \\
& guidance and counseling teacher performance specifically services to the \\
& students and technical facilities as a media to help guidance and counseling \\
& teacher directed students to make their decisions. The purpose of this research \\
& is to know the relationship of principal leadership, teacher performance \\
& guidance counseling and a technical facility with self-students development. \\
& This research uses descriptive analysis method of correlation with the \\
& quantitative approach. Data collection by questionnaires. The sample used \\
purposive sampling at senior high school in Banten province. The results show & a relationship principal leadership with self-students development, guidance \\
and counseling teacher performance with self-students development, technical \\
facility with self-students development, the relationship of principal leadership, \\
guidance and counseling teacher performance and technical facilities with self- \\
students development. The effort of self-students development can be \\
improving by principal leadership, guidance, and counseling teacher \\
performance and technical facilities.
\end{tabular}

KEYWORDS: Guidance and Counseling, High School, Self-Development.

DOI: 10.30653/001.202041.114

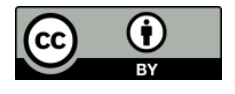

This is an open access article distributed under the terms of the Creative Commons Attribution 4.0 International License, which permits unrestricted use, distribution, and reproduction in any medium, provided the original work is properly cited. ๑) 2020 Salman Tumanggor.

\section{PENDAHULUAN}

Sekolah merupakan sebuah organisasi yang unik, karena terdiri dari berbagai macam individu mulai dari latar belakang usia, sosial, ekonomi, budaya, tujuan, dan lain sebagainya. Hal tersebut diperlukan suatu badan internal sekolah yang bertugas dan berfungsi selain mengembangkan potensi individu-indivindu, juga membantu mengatasi

\footnotetext{
${ }^{1}$ Corresponding author's address: Program Studi Manajemen Pendidikan Islam Program Pascasarjana Universitas Islam Negeri Syarif Hidayatullah Jakarta; Jl. Ciputat Raya Cirendeu Jakarta, Indonesia. Email: salmantumanggor2019@ gmail.com
} 
berbagai masalah yang timbul di sekolah tersebut. Untuk mengembangkan potensi individu yang dalam hal ini kalau di sekolah disebut anak didik, namun bimbingan dan konseling agak tertinggal dan bisa dikatakan terabaikan.

Penyelenggaraan program bimbingan dan konseling di sekolah untuk mendukung pencapaian tujuan pendidikan sekolah secara keseluruhan. Adapun tujuannya dasarnya untuk menyiapkan peserta didik melalui kegiatan bimbingan, pengajaran, dan latihan bagi peranannya di masa yang akan datang.

Diantara upaya pengembangan diri siswa terutama tingkat menengah atas melalui pendekatan kepemimpinan kepala sekolah memberi dorongan kepada seluruh sumberdaya yang ada di sekolah, kinerja guru bimbingan dan konseling yang secara khusus memberikan layanan kepada siswa dan fasilitas teknik sebagai media dalam membantu guru bimbingan dan konseling mengarahkan siswa untuk bersikap atau mengambil keputusan tertentu.

Berdasarkan hasil observasi Agus Suhara (2005, p. 6) di Kota Bandung menyatakan bahwa guru bimbingan dan konseling baru terpenuhi 43,58 \% (34 orang), sedangkan yang layak sebagai guru bimbingan dan konseling baru 20,50\% (16 orang) yang tidak layak $23,07 \%$ (18 orang). Dengan demikian sekolah masih memerlukan 79,50\% (69 orang) guru bimbingan dan konseling.

Kurangnya fasilitas pendukung layanan bimbingan dan konseling di sekolah, misalnya tidak mempunyai ruang bimbingan dan konseling, tidak tersedia lemari penyimpan data, tidak ada ruang khusus Bimbingan /konseling kelompok, tidak tersedia komputer, tidak tersedia papan informasi, meja kursi dan keterbatasan lainnya.

Guru bimbingan dan konseling kurang mampu membuat program layanan yang realistis yang dapat diterapkan disekolah, guru bimbingan dan konseling mampu membuat program namum hanya sebatas administrasi artinya tidak dilaksanakan dengan sungguh-sungguh sehingga tidak dirasakan oleh siswa dan rekan sejawat, banyak program layanan yang tidak dikuasai oleh guru bimbingan dan konseling, mereka hanya menguasai program layanan orentasi, informasi, dan sebagian penempatan, sementara layanan lainya yang lebih penting seperti layanan konten, bimbingan kelompok,konseling kelompok, bahkan konseling individu sebagai roh dari program bimbingan dan konseling jarang dilakukan karena kurang dikuasai.

Empat bidang bimbingan dalam bimbingan dan konseling yaitu, bidang karir, bidang belajar, bidang pribadi dan bidang sosial merupakan ruang ruang profesional konselor dalam melakukan kegiatan layanan dan bimbingan secara profesional, yang harus dijalankan konselor untuk membantu siswa secara optimal dan mandiri.

Gysbers dan Handerson (2012, p. 67) menunjukkan bahwa evaluasi kinerja konselor (counselor performance evaluation), evaluasi kinerja konselor (counselor performance evaluation), dan evaluasi hasil (result evaluation). Evaluasi kinerja konselor memusatkan perhatian pada penilaian unjuk kerja konselor dan kemampuan membawakan diri sebagai konselor. Evaluasi program (program evaluation) memusatkan perhatian pada penilaian mutu pelaksanaan program bimbingan dan konseling yang sudah dirancang. Evaluasi hasil (result evaluation) memusatkan perhatian penilaian atas hasil dan dampak program bimbingan dan konseling (outcomes and impact). 
Burhasman, (2008, p. 3) mengemukakan bahwa pengembangan diri adalah pelayanan bantuan untuk siswa baik individu maupun kelompok agar berkembang secara optimal dalam hubungan pribadi, sosial, belajar, dan karir, melalui proses pembiasaan, pemahaman diri dan lingkungan serta manfaatnya untuk mencapai kesempurnaan perkembangan diri. Pelayanan ini bertujuan memandirikan siswa dengan berkembangnya potensi, bakat, serta keunikan diri bagi kebahagiaan hidupnya.

Pelayanan bimbingan dan konseling merupakan salah satu komponen penting pendidikan di sekolah. Tujuannya adalah untuk membantu perkembangan potensi diri siswa seoptimal mungkin. Kegiatan belajar berorientasi pada peningkatan kecerdasan siswa, maka kegiatan bimbingan dan konseling di sekolah secara spesifik berorientasi membantu seluruh aspek-aspek perkembangan diri siswa (Jamal Ma'mur Asmani, 2010, p. 50)

Menurut Sulistyowati (2012, p. 60), pengembangan diri merupakan kegiatan pendidikan di luar mata pelajaran sebagai bagian integral dari kurikulum sekolah. Kegiatan pengembangan diri merupakan upaya pembentukan watak dan kepribadian peserta didik yang dilakukan melalui kegiatan pelayanan konseling berkenaan dengan masalah pribadi dan kehidupan sosial, kegiatan belajar, dan pengembangan karir, serta kegiatan ekstra kurikuler.

Pengembangan diri yang menjadi garapan bimbingan dan konseling adalah berkaitan dengan pengembangan bakat, minat, kemampuan, kepribadian, serta tugastugas perkembangan yang berkaitan dengan peserta didik baik di SMP maupun SMA. Dalam pelaksanaan bimbingan dan konseling di sekolah meteri pengembangan diri akan terbagi menjadi empat bidang yaitu: bidang bimbingan pribadi,sosial, belajar dan karir. Sedangkan pengembangan diri yang berkaitan dengan skill dan atau ketrampilan seperti paskibra, sepak bola, pramuka, UKS , pencinta alam, karate, KIR, dan sebagainya dapat dilaksanakan melalui kegiatan ektrakurikuler yang pembinaanya disekolah dapat melalui wakasek kesiswaan atau guru pembina yang menguasai bidang dimaksud.

Peran dari guru bimbingan dan konseling itu sendiri dituntut harus profesional dan mempunyai jiwa sabar, ikhlas dan mau berkorban untuk suatu perubahan anak didik untuk mengembangkan poensinya maupun membantu mereka yang menemui kendala. Ujung-ujungnya yang sangat strategis adalah peran kepala sekolah yang harus mempunyai visi tentang bimbingan dan konseling yang merupakan tangan kanannya untuk mencapai tujuan pendidikan (Kulsum, 2013, p. 68).

Kepala sekolah sebagai manajer pada intinya adalah melaksanakan fungsi manajemen sebagaimana yang dikemukakan oleh Terry (1997:4) yang menjelaskan pengertian manajemen adalah sebagai berikut "Management is a distinc process consisting of planning, organizing, actualiting, and controlling, performed to determine and accomplish atated objectives by the use of human beings and other resources". Manajemen adalah proses yang jelas yang meliputi perencanaan, pengorganisasian, penggerakan dan pengawasan yang diselenggarakan untuk mencapai tujuan yang telah ditetapkan dengan potensi manusia dan sumberdaya lainnya. Kepemimpinan kepala sekolah dalam kerangka menajemen pendidikan merupakan kemampuan yang dimiliki seseorang untuk merencanakan mengimplementasikan, mengendalikan, mengawasi dan mengevaluasi atas jalannya seluruh kegiatan organisasi sekolah. (Hidayat \& Machali, 2012, p. 75). 
Kepala sekolah sebagai seorang manajer berperan merencanakan kebijakan penambahan mata pelajaran bimbingan dan konseling dengan waktu dua jam per minggu (Royadi \& Pardjono, 2015, p. 124)

Hasil penelitian menunjukkan bahwa tiga belas sekolah berada pada kategori tidak memenuhi standar $(92,8 \%)$ dan satu sekolah berada pada kategori memenuhi standar $(7,14 \%)$. Pada aspek ruang bimbingan dan konseling seluruh sekolah tidak memenuhi standar (100\%). Pada aspek instrumen pengumpul data tiga belas sekolah berada pada kategori memenuhi standar (92,8\%) dan satu sekolah tidak memenuhi standar $(7,14 \%)$. Pada aspek kelengkapan penunjang teknis sepuluh sekolah memenuhi standar $(71,4 \%)$ dan empat sekolah lainnya tidak memenuhi standar (28,6\%). (Intishar, Chanum, \& Badrujaman, 2015, p. 25).

Sarana bimbingan dan konseling sebagai peralatan dan perlengkapan yang sangat penting dan dibutuhkan yang menunjang keterlaksanaan program bimbingan dan konseling (Gysbers, 2008, p. 216). Sarana dan prasarana bimbingan dan konseling adalah peralatan dan perlengkapan yang menunjang tercapainya tujuan layanan bimbingan dan konseling (Kemendikbud, 2014:32). Berdasarkan pengertian di atas sarana bimbingan dan konseling merupakan seluruh peralatan dan perlengkapan yang dibutuhkan dalam penyelenggaraan bimbingan dan konseling.

1) Kepemimpinan Kepala Sekolah

Kemampuan yang dimiliki seseorang untuk merencanakan mengimplementasikan, mengendalikan, mengawasi dan mengevaluasi atas jalannya seluruh kegiatan organisasi/persekolahan.

2) Kinerja Guru bimbingan dan konseling

Kinerja Guru bimbingan dan konseling adalah prestasi kerja seorang guru bimbingan dan konseling yang merupakan hasil yang dicapai oleh guru bimbingan dan konseling dalam melaksanakan tugas-tugas yang dibebankan kepadanya yang didasari atas kecakapan, pengalaman dan kesungguhan serta penggunaan waktu. Kinerja guru bimbingan dan konseling adalah kemampuan kerja yang ditunjukkan dalam tingkah laku yang ditampilkan oleh guru bimbingan dan konseling dalam melakukan pekerjaannya secara efektif dan efisien. Kinerja guru bimbingan dan konseling menyusun manajemen bimbingan konseling adalah serangkaian kegiatan yang disusun oleh guru bimbingan konseling dalam satu tahun ajaran.

3) Fasilitas Teknik bimbingan dan konseling

Fasilitas teknik bimbingan dan konseling yaitu fasilitas yang berfungsi mempermudah konselor dalam melakukan pelayanan terhadap konseli yaitu mudah dipakai, mudah diatur, simpel dan tidak rumit serta dinamis. Fasilitas teknik bimbingan dan konseling yaitu fasilitas yang berkaitan dengan pemanfaatan/penggunaan teknologi informasi dalam proses konseling yang pada gilirannya terwujudnya efektif dan efisiennya suatu layanan.

4) Pengembangan Diri

Pengembangan diri adalah proses pembentukan sikap dan perilaku yang relatif menetap melalui pengalaman berulang-ulang sampai pada tahap otonomi (kemandirian) mengenai suatu perilaku tertentu. Pengembangan diri merupakan keseluruhan proses 
sosial dan budaya dilingkungan peserta didik dalam upaya mendukung berkembangnya keseluruhan proses peserta didik secara utuh dan menyeluruh serta berlangsung sepanjang perjalanan dan konteks kehidupan dalam lingkungannya.

Pengembangan diri juga adalah pengembangan manajemen yaitu suatu tanggapan yang dilakukan oleh seseorang secara sadar mengenai apa yang dianggap sebagai kebutuhan dalam rangka pengembangan dirinya.

\section{METODE}

Penelitian menggunakan metode analisis korelasi dengan pendekatan kuantitatif. Data kuantitatif akan dianalisis dengan statistik korelasional, sehingga secara lengkap metode yang digunakan deskriptif analitik korelasional. Dalam pengumpulan data ditempuh dengan melakukan penyebaran angket (daftar pertanyaan) yang sebelumnya dilakukan uji validitas dan reliabiltas

Teknik pengambilan sampel dalam penelitian ini digunakan secara acak sederhana (simple random sampling) dari 5 (lima) sekolah SMA Negeri di Kota Tangerang Selatan Provinsi Banten dengan jumlah sampel sebesar 254 orang.sampel diambil secara acak sederhana (random sampling).

Analisa data akan dilakukan dengan menghitung korelasi dan regrasi secara parsial maupun multiple dengan menggunakan koefisien korelasi dari Product Moment Pearson. Uji persyaratan analisis menggunakan bantuan komputer program SPSS Versi 23.00 for Windows.

Uji coba instrumen pengembangan diri sisiwa (PDS) diperoleh 120 butir valid, sedangkan pernyataan yang drop 0 dengan koefisien reliabilitas 0,978 . Uji coba instrumen kepemimpinan kepala sekolah (KKS) diperoleh 40 butir valid dan 0 butir drop dengan koefisien reliabilitas 0,930. Uji coba instrumen kinerja guru bimbingan dan konseling (KGBK) diperoleh 80 butir valid dan 0 butir drop dengan koefisien reliabilitas 0,965. Uji coba instrumen fasilitas teknik (FT) diperoleh 40 butir valid dan 0 butir drop dengan koefisien reliabilitas 0,948 .

Pertama dihitung nilai-nilai $\mathrm{Y}, \mathrm{Y}_{i}$ dan $(\mathrm{Y}-\hat{\mathrm{Y}})$ berdasarkan persamaan regresi $\hat{\mathrm{Y}}=$ $405,953+0,736 X_{1}$ dan hasilnya dikonfirmasikan dengan hasil perhitungan komputer sebesar 0,142 sehingga $H_{0}$ diterima. Ini berarti galat baku taksiran dari persamaan regresi $\hat{Y}=405,953+0,736 X_{1}$ berdistribusi normal $(\mathrm{KS}=0,000)$.

Pertama dihitung nilai-nilai $\mathrm{Y}, \mathrm{Y}_{i}$ dan $(\mathrm{Y}-\hat{\mathrm{Y}})$ berdasarkan persamaan regresi $\hat{\mathrm{Y}}=$ $126,023+1,137 \mathrm{X}_{2}$ dan hasilnya dikonfirmasikan dengan hasil perhitungan komputer sebesar 0,138 sehingga Ho diterima. Ini berarti galat baku taksiran dari persamaan regresi $\hat{Y}=126,023+1,137 \mathrm{X}_{2}$ berdistribusi normal $(\mathrm{KS}=0,000)$.

Pertama dihitung nilai-nilai $\mathrm{Y}, \mathrm{Y}_{\mathrm{i}}$ dan $(\mathrm{Y}-\hat{\mathrm{Y}})$ berdasarkan persamaan regresi yaitu $\hat{Y}$ $=272,495+1,411 X_{3}$ dan hasilnya dikonfirmasikan dengan hasil perhitungan komputer sebesar 0,109 sehingga $\mathrm{H}_{0}$ diterima. Ini berarti galat baku taksiran dari persamaan regresi yaitu $\hat{Y}=272,495+1,411 \mathrm{X}_{3}$ berdistribusi normal $(\mathrm{KS}=0,000)$. 
Tabel 1. Hasil Uji Normalitas

\begin{tabular}{clccl}
\hline No & Regresi $Y$ atas $\mathrm{X}_{\mathrm{i}}$ & Nilai Lhitung & Nilai Ltabel & Keputusan \\
\hline 1. & Regresi $\mathrm{Y}$ atas $\mathrm{X}_{1}$ & 0,142 & 0,05 & NORMAL \\
2. & Regresi $\mathrm{Y}$ atas $\mathrm{X}_{2}$ & 0,138 & 0,05 & NORMAL \\
3. & Regresi $\mathrm{Y}$ atas $\mathrm{X}_{3}$ & 0,109 & 0,05 & NORMAL \\
\hline
\end{tabular}

\section{HASIL DAN PEMBAHASAN}

Hubungan antara kepemimpinan kepala sekolah dengan pengembangan diri siswa ditunjukkan oleh persamaan regresi $\hat{Y}=405,953+0,736 X_{1}$. Berdasarkan uji signifikansi dan uji kelinearan regresi tersebut di atas, maka disimpulkan bahwa persamaan regresi $\hat{Y}$ $=405,953+0,736 X_{1}$ signifikan dan linear. Persamaan regresi tersebut menunjukkan bahwa setiap perubahan satu skor kepemimpinan kepala sekolah akan menyebabkan kenaikan 0,736 skor pengembangan diri siswa pada konstanta 405,953. Kekuatan hubungan antara kepemimpinan Kepala Sekolah dengan pengembangan diri siswa ditunjukkan oleh koefisien korelasi $\mathrm{r}_{\mathrm{y} 1}=0,495$.

Berdasarkan uji signifikansi koefisien korelasi tersebut disimpulkan bahwa koefisien korelasi antara kepemimpinan kepala sekolah dengan pengembangan diri siswa sebesar 0,301 adalah sangat signifikan. Dengan demikian terdapat hubungan positif antara kepemimpinan kepala sekolah dengan pengembangan diri siswa atau dengan kata lain makin tinggi kepemimpinan kepala sekolah, maka kinerjanya juga makin tinggi. Koefisien determinasinya adalah $\mathrm{r}^{2}=(0,495)^{2}=0,245$ atau 24,5\%. Koefisien korelasi antara kepemimpinan kepala sekolah dengan pengembangan diri siswa sebesar 0,495, dengan koefisien determinasi sebesar 0,245 atau $24,5 \%$ berarti bahwa $24,5 \%$ variasi pengembangan diri siswa dapat ditentukan oleh kepemimpinan kepala sekolah.

Hubungan antara kinerja guru bimbingan dan konseling dengan pengembangan diri siswa ditunjukkan oleh persamaan regresi $\hat{Y}=126,023+1,137 \mathrm{X}_{2}$. Berdasarkan uji signifikansi dan uji kelinearan regresi tersebut di atas, maka disimpulkan bahwa persamaan regresi $\hat{Y}=126,023+1,137 X_{2}$ signifikan dan linear. Persamaan regresi tersebut menunjukkan bahwa setiap kenaikan satu skor kinerja guru bimbingan dan konseling akan menyebabkan kenaikan 1,337 skor pengembangan diri siswa pada konstanta 126,023 .

Kekuatan hubungan antara kinerja guru bimbingan dan konseling dengan pengembangan diri siswa ditunjukkan oleh koefisien korelasi $r_{y} .2=0,945$. Berdasarkan uji signifikansi koefisien korelasi tersebut disimpulkan bahwa koefisien korelasi antara kinerja guru bimbingan dan konseling dengan pengembangan diri siswa sebesar 0,945 adalah sangat signifikan. Dengan demikian terdapat hubungan positif antara kinerja guru bimbingan dan konseling dengan pengembangan diri siswa atau dengan kata lain makin tinggi kinerja guru bimbingan dan konseling, maka pengembangan diri siswa juga makin tinggi. Koefisien determinasinya adalah $\mathrm{r}^{2}=(0,945)^{2}=0,8920$ atau $89,20 \%$. Koefisien korelasi antara kinerja guru bimbingan dan konseling dengan pengembangan diri siswa sebesar 0,945, dengan koefisien determinasi sebesar 0,8920 atau 89,20\% berarti bahwa $89,20 \%$ variasi pengembangan diri siswa dapat ditentukan oleh kinerja guru bimbingan dan konseling. 
Hubungan antara fasiltas teknik dengan pengembangan diri siswa ditunjukkan oleh persamaan regresi $\hat{Y}=128,582+0,376 X_{3}$. Berdasarkan uji signifikansi dan uji kelinearan regresi tersebut di atas, maka disimpulkan bahwa persamaan regresi $\hat{Y}=272,495+1,411$ $\mathrm{X}_{3}$ signifikan dan linear. Persamaan regresi tersebut menunjukkan bahwa setiap kenaikan satu skor fasiltas teknik akan menyebabimbingan dan konselingan kenaikan 0,376 skor pengembangan diri siswa pada konstanta $272,495+1,411$. Kekuatan hubungan antara fasiltas teknik dengan pengembangan diri siswa $(\mathrm{Y})$ ditunjukkan oleh koefisien korelasi $\mathrm{r}_{\mathrm{y}}$ $=0,545$.

Berdasarkan uji signifikansi koefisien korelasi tersebut disimpulkan bahwa koefisien korelasi antara fasiltas teknik dengan pengembangan diri siswa sebesar 0,545 adalah sangat signifikan. Dengan demikian terdapat hubungan positif antara fasiltas teknik dengan pengembangan diri siswa atau dengan kata lain makin tinggi fasiltas teknik, maka pengembangan diri siswa juga makin tinggi. Koefisien determinasinya adalah $\mathrm{r}^{2}=(0,545)^{2}$ $=0,2970$ atau $29,70 \%$. Koefisien korelasi antara fasiltas teknik dengan pengembangan diri siswa sebesar 0,545 , dengan koefisien determinasi sebesar 0,2970 atau $29,70 \%$ berarti bahwa $29,70 \%$ variasi pengembangan diri siswa dapat ditentukan oleh fasilitas teknik.

Hubungan positif antara kepemimpinan kepala sekolah, kinerja guru bimbingan dan konseling serta fasiltas teknik secara bersama-sama dengan pengembangan diri siswa ditunjukkan oleh persamaan regresi jamak $\hat{Y}=32,399+0,016 X_{1}+1,026 X_{2}+0,750 X_{3}$.

Berdasarkan uji signifikansi tersebut disimpulkan bahwa regresi jamak $\hat{Y}=32,399+$ $0,016 X_{1}+1,026 X_{2}+0,750 X_{3}$ signifikan. Ini berarti terdapat hubungan positif antara kepemimpinan kepala sekolah, kinerja guru bimbingan dan konseling serta fasiltas teknik secara bersama-sama dengan pengembangan diri siswa. Kekuatan hubungan antara kepemimpinan kepala sekolah, kinerja guru bimbingan dan konseling serta fasiltas teknik secara bersama-sama dengan pengembangan diri siswa ditunjukkan oleh $\mathrm{r}_{\mathrm{y} \cdot 123}=0,984$.

Berdasarkan uji signifikansi koefisien korelasi jamak tersebut disimpulkan bahwa hubungan positif antara kepemimpinan kepala sekolah, kinerja guru bimbingan dan konseling serta fasiltas teknik secara bersama-sama dengan pengembangan diri siswa $r_{\mathrm{y}}$ $123=0,984$ dan koefisien determinasi $\mathrm{r}^{2}=(0,984)^{2}=0,9690$ atau $96,90 \%$. Ini berarti $96,90 \%$ variasi pengembangan diri siswa $(\mathrm{Y})$ dapat ditentukan atau dijelaskan oleh kepemimpinan kepala sekolah, kinerja guru bimbingan dan konseling serta fasiltas teknik secara bersama-sama.

Meskipun hasil uji perbedaan koefisien korelasi antara $\mathbf{r}_{\mathrm{y} 1}, \mathbf{r}_{\mathbf{y} 2}$ dan $\mathbf{r}_{\mathrm{y} 3}$ tidak terdapat perbedaan yang signifikan, namun demikian peningkatan pengaruh dari masing-masing variabel bebas terhadap variabel terikat dapat dilihat berdasarkan urutan besarnya koefisien korelasi parsial sebagaimana terlihat pada Tabel 2.

Tabel 2. Urutan Peningkatan Menurut Besarnya Koefisien Korelasi Parsial

\begin{tabular}{ccc}
\hline Nomor & Koefisien Korelasi Parsial & Peningkatan \\
\hline 1 & $r_{y 2.13}=0,945$ & Pertama \\
\hline 2 & $r_{\mathrm{y} 3.21}=0,545$ & Kedua \\
\hline 3 & $r_{y 1.23}=0,495$ & Ketiga \\
\hline
\end{tabular}

Tabel 2 menunjukkan bahwa koefisien korelasi parsial tertinggi adalah kinerja guru bimbingan dan konseling dengan $r_{y 2.13}=0,945$, koefisien korelasi parsial kedua adalah 
fasiltas teknik dengan $r_{y 3.12}=0,545$ dan koefisien korelasi parsial ketiga adalah kepemimpinan kepala sekolah dengan $\mathrm{r}_{\mathrm{y} 1.23}=0,495$.

Pengujian hipotesis pertama, bahwa terdapat hubungan positif antara kepemimpinan kepala sekolah dengan pengembangan diri siswa, diperoleh $r$ sebesar 0,495 dengan koefisien determinasi $r^{2}=0,2450$. Artinya keeratan hubungan antara kepemimpinan kepala sekolah dengan pengembangan diri siswa terbukti ada benarnya berdasarkan penelitian. Dengan kata lain kepemimpinan kepala sekolah memiliki pengaruh terhadap pengembangan diri siswa yang cukup berarti. Dari hasil pengujian ternyata kepemimpinan kepala sekolah dapat memprediksi pengembangan diri siswa melalui persamaan regresi sederhana $\hat{Y}=405,953+0,736 X_{1}$ telah terbukti bahwa model ini adalah signifikan. Seperti telah dijelaskan di atas, hasil perhitungan korelasi sederhana diperoleh koefisien korelasi $\mathrm{r}$ sebesar 0,495 dengan koefisien determinasi $\mathrm{r}^{2}=0,2450$. Berarti sumbangan kepemimpinan kepala sekolah terhadap pengembangan diri siswa sebesar $24,50 \%$ selebihnya variabel lain. Hal ini senada dengan hasil penelitian Gaol (2017) yang mengungkapkan bahwa kepemimpinan manajerial kepala sekolah sebenarnya memberikan dampak positif terhadap sekolah. Karena dengan kemampuan mengorganisir program yang dimiliki oleh kepala sekolah akan membawa suasana edukatif dan tidak membosankan bagi guru dan peserta didik yang berada di lingkungan sekolah. Selain membuat program sekolah terlaksana dengan baik, kepemimpinan manajerial juga dapat memberikan dampak postif terhadap guru-guru di sekolah. Selain itu juga Kulsum (2013) menyatakan bahwa ujung-ujungnya yang sangat strategis adalah peran kepala sekolah yang harus mempunyai visi tentang bimbingan dan konseling yang merupakan tangan kanannya untuk mencapai tujuan pendidikan.

Pengujian hipotesis kedua, bahwa terdapat hubungan positif antara kinerja guru bimbingan dan konseling dengan pengembangan diri siswa, diperoleh $\mathrm{r}$ sebesar 0,945 dengan koefisien determinasi $r^{2}=0,8920$. Artinya keeratan hubungan antara kinerja guru bimbingan dan konseling dengan pengembangan diri siswa terbukti ada benarnya berdasarkan penelitian. Dengan kata lain kinerja guru bimbingan dan konseling memiliki pengaruh terhadap pengembangan diri siswayang cukup berarti. Dari hasil pengujian ternyata kinerja guru bimbingan dan konseling dapat memprediksi pengembangan diri siswa melalui persamaan regresi sederhana $\hat{Y}=126,023+1,137 \mathrm{X}_{2}$ telah terbukti bahwa model ini adalah signifikan. Seperti telah dijelaskan di atas, hasil perhitungan korelasi sederhana diperoleh koefisien korelasi $\mathrm{r}$ sebesar 0,945 dengan koefisien determinasi $\mathrm{r}^{2}=$ 0,8920. Berarti sumbangan kinerja guru bimbingan dan konseling terhadap pengembangan diri siswasebesar $89,20 \%$ selebihnya variabel lain. Sebagaimana pendapat Kulsum bahwa peran dari guru bimbingan dan konseling itu sendiri dituntut harus profesional dan mempunyai jiwa sabar, ikhlas dan mau berkorban untuk suatu perubahan anak didik untuk mengembangkan potensinya maupun membantu mereka yang menemui kendala. Kinerja guru bimbingan dan konseling salah satu upaya agar layanannya memiliki standar, Wenny Hulukati (2013) mengungkapkan berdasarkan hasil keefektifan produk pengembangan diri diperoleh informasi bahwa perangkat panduan pengembangan diri akan efektif digunakan untuk meningkatkan kompetensi guru bimbingan konseling sehinga akan meningkatkan pengembangan diri siswa.

Pengujian hipotesis ketiga, bahwa terdapat hubungan positif antara fasiltas teknik dengan pengembangan diri siswa, diperoleh $\mathrm{r}$ sebesar 0,545 dengan koefisien determinasi $r^{2}=0,2970$. Artinya keeratan hubungan antara fasiltas teknik dengan pengembangan diri 
siswa terbukti ada benarnya berdasarkan penelitian. Dengan kata lain fasiltas teknik memiliki pengaruh terhadap pengembangan diri siswa yang cukup berarti. Dari hasil pengujian ternyata fasiltas teknik dapat memprediksi pengembangan diri siswa melalui persamaan regresi sederhana $\hat{Y}=272,495+1,411 \mathrm{X}_{3}$ telah terbukti bahwa model ini adalah signifikan. Seperti telah dijelaskan di atas, hasil perhitungan korelasi sederhana diperoleh koefisien korelasi $\mathrm{r}$ sebesar 0,545 dengan koefisien determinasi $\mathrm{r}^{2}=0,2970$. Berarti sumbangan fasiltas teknik terhadap pengembangan diri siswa sebesar $29,70 \%$ selebihnya variabel lain. Hal ini senada yang diungkapkan Intishar, Chanum, dan Badrujaman (2015) yang melakukan penelitian di SMA DKI Jakarta menunjukkan bahwa tiga belas sekolah berada pada kategori tidak memenuhi standar $(92,8 \%)$ dan satu sekolah berada pada kategori memenuhi standar (7,14\%). Pada aspek ruang bimbingan dan konseling seluruh sekolah tidak memenuhi standar (100\%). Dengan fasiltas teknik layanan bimbingan dan konseling yang tidak memenuhi standar atau kurang, maka akan mengurangi pengembangan diri siswa dan jusru sebaliknya jika fasilitas teknik memenuhi standar akan memberikan layanan pengembangan diri siswa yang lebih baik. Begitu pula yang dikatakan Gysber bahwa sarana bimbingan dan konseling sebagai peralatan dan perlengkapan yang sangat penting dan dibutuhkan yang menunjang keterlaksanaan program bimbingan dan konseling.

Pembahasan interpretasi hasil penelitian yang merujuk pada kenyataan empirik dan hasil penelitian relevan lainnya, membuktikan bahwa temuan penting yang didapatkan dalam penelitian ini adalah terdapat hubungan positif antara kepemimpinan kepala sekolah, kinerja guru bimbingan dan konseling dan fasiltas teknik secara sendiri maupun bersama dengan kinerja guru.

\section{SIMPULAN}

Ada hubungan kepemimpinan kepala sekolah dengan pengembangan diri siswa, ada hubungan kinerja guru bimbingan dan konseling dengan pengembangan diri siswa, ada hubungan fasilitas teknik dengan pengembangan diri siswa, ada hubungan kepemimpinan kepala sekolah, kinerja guru bimbingan dan konseling serta fasilitas teknik secara bersama dengan pengembangan diri siswa. Dengan demikian upaya peningkatan pengembangan diri siswa dengan kepemimpinan kepala sekolah, kinerja guru bimingan dan koseling serta fasilitas teknik.

\section{REFERENSI}

Burhasman. (2008). Pelayanan konseling di sekolah dalam pengembangan diri siswa. Makalah disampaikan dalam Konnvensi Nasional II Ikatan Konselor Indonesia (IKI) dan Seminar Internasional Konseling di Padang, 30-31 Maret.

Gysbers, N.C \& Henderson, P. (2012). Developing managing your school guidance and counseling program. Alexandria, VA: ACA.

Gysbers, N.C. (2008). Evaluating school guidance and counseling programs: Past present and future, dalam Coleman HLK \& Yeh, C (Ed.), Handbook of School Counseling New York, London: Routledge. 
Gaol, N. T. L. (2017). Teori dan implementasi gaya kepemimpinan kepala sekolah. Kelola: Jurnal Manajemen Pendidikan, 4(2), 213-219.

Hidayat, A., \& Machali, I. (2012). Pengelolaan pendidikan, konsep, prinsip, dan aplikasi dalam mengelola sekolah dan madrasah. Yogyakarta: Kaukaba.

Intishar, F., Chanum, I., \& Badrujaman, A. (2015). Pemenuhan standar sarana dan prasarana bimbingan dan konseling (Survei terhadap sekolah menengah atas negeri di Jakarta Barat). INSIGHT: Jurnal Bimbingan Konseling, 4(1), 25-31.

Kemendikbud. (2014). Pedoman bimbingan dan konseling pada pendidikan dasar dan pendidikan menengah. Jakarta: Kementerian Pendidikan dan Kebudayaan.

Kulsum, S. (2013). Peranan bimbingan dan konseling dalam domain pengembangan diri siswa. Jurnal Konseling dan Pendidikan 1(1), 67-72.

Rosyadi, Y. I., \& Pardjono. (2015). Peran kepala sekolah sebagai manajer dalam meningkatkan mutu pendidikan di SMP 1 Cilawu Garut. Jurnal Akutabilitas Manajemen Pendidikan 3(1), 124-133.

Suslistyowati, E. (2012). Implementasi kurikulum pendidikan karakter. Yogyakarta: Citra Aji Parama.

Setiyowati, S. (2013). Hubungan antara persepsi siswa terhadap pribadi konselor dan fasilitas bimbingan dan konseling dengan minat siswa untuk memanfaatkan layanan konseling di sekolah. Jurnal Bimbingan dan Konseling Unesa 3(1), 78-95.

Terry, G.R. (1997). Prinsip-prinsip Manajemen. Jakarta: Bumi Aksara.

Wenny Hulukati. (2013). Perangkat pengembangan diri untuk meningkatkan kompetensi guru dan pengembangan kepribadian siswa SMA. Jurnal Ilmu Pendidikan 19(2), 136141. 